\title{
A national survey of tooth wear on facial and oral surfaces and risk factors in young Nigerian adults
}

\author{
Kofoworola Olaide Savage ${ }^{1}$, Olabisi Hajarat Oderinu², llemobade Cyril Adegbulugbe ${ }^{2}$, \\ Omolara Gbonjubola $\mathrm{Uti}^{1}$, Oluwole Oyekunle Dosumu ${ }^{3}$, Adeyemi Oluniyi Olusile ${ }^{4}$
}

Correspondence: Dr. Olabisi Hajarat Oderinu

Email: bisioderinu@yahoo.co.uk

\author{
'Department of Preventive Dentistry, Faculty of Dental \\ Sciences, College of Medicine, University of Lagos, \\ Lagos, Nigeria, \\ ${ }^{2}$ Department of Restorative Dentistry, Faculty of Dental \\ Sciences, College of Medicine, University of Lagos, \\ Lagos, Nigeria, \\ ${ }^{3}$ Department of Restorative Dentistry, Faculty of \\ Dentistry, University of Ibadan, Ibadan, Nigeria, \\ ${ }^{4}$ Department of Restorative Dentistry, Faculty of \\ Dentistry, College of Health Sciences, Obafemi \\ Awolowo University, lle-Ife, Nigeria
}

\section{ABSTRACT}

Objective: The objective of this study is to assess the prevalence of tooth wear and to identify risk factors in a sample of young Nigerian adults. Materials and Methods: Participants were individuals aged 18-35 years, attending dental clinics located in eight centers representing the six geopolitical zones of the country. Calibrated examiners measured tooth wear using basic erosive wear examination (BEWE) index. Individuals were characterized by the highest BEWE score recorded for any facial/oral tooth surface. Previously validated questionnaire was used to gather information on demographics and risk factors. Results: A total of 1349 participants were examined. The prevalence of tooth wear was $60.2 \%$. Bivariate analysis showed significant differences in the prevalence of tooth wear with age, educational level, and occupation $(P \leq 0.05)$. There were significant differences in tooth wear among the participants from the different states. Tooth wear was found to increase with smoking. Tooth wear was associated with brushing frequency, use of chewing stick, and other local cleaning agents. Multiple regression analysis showed that age, brushing frequency, brushing after breakfast added statistically significantly to the prediction of tooth wear $(P<0.05)$. Conclusion: Tooth wear was common in the population. The frequency of tooth brushing, use of chewing sticks and other local tooth cleaning agents may be contributory.

Key words: Facial/oral tooth surface wear, prevalence, risk factors

\section{INTRODUCTION}

Tooth wear is common in contemporary humans, and it occurs sooner or later in life. ${ }^{[1]}$ It is a physiologic process which becomes pathologic if the "teeth become so worn that they do not function effectively or seriously mar the appearance." ${ }^{[2]}$ The condition arise

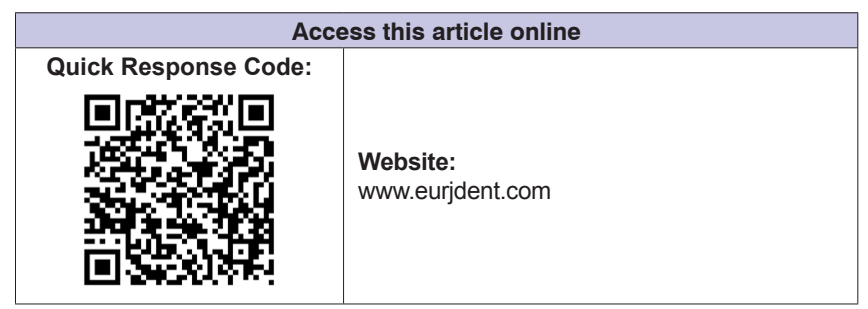

because of different physical and chemical impacts acting on the tooth surfaces to change the anatomy. Described clinical subtypes include abrasion, attrition, erosion, and abfraction. ${ }^{[3,4]}$ Clinical diagnosis

This is an open access journal, and articles are distributed under the terms of the Creative Commons Attribution-NonCommercial-ShareAlike 4.0 License, which allows others to remix, tweak, and build upon the work non-commercially, as long as appropriate credit is given and the new creations are licensed under the identical terms.

For reprints contact: reprints@medknow.com

How to cite this article: Savage $\mathrm{KO}$, Oderinu $\mathrm{OH}$, Adegbulugbe IC, Uti OG, Dosumu OO, Olusile AO. A national survey of tooth wear on facial and oral surfaces and risk factors in young Nigerian adults. Eur $\mathrm{J}$ Dent 2018;12:292-9.

DOI: 10.4103/ejd.ejd_92_17 
is often challenging because most cases result from a combination of etiologic factors, one of which may predominate ${ }^{[3]}$ Hence, detailed dietary, oral hygiene, occupation, medical, and dental history are necessary to identify etiology or risk factors which is cardinal in the prevention and successful management of the worn dentition. Report of studies ${ }^{[5-7]}$ support that tooth wear is common in both young and adults. Other studies ${ }^{[8-10]}$ also identified risk factors in the population studied. Available data ${ }^{[11,12]}$ on prevalence and risk factors for tooth wear in Nigeria is limited to selected population groups hence the need for this national survey in our multiethnic and cultural population.

This study determined the prevalence of tooth wear on facial/oral (palatal/lingual) tooth surfaces and identified possible risks factors from young adults (18-35 years). Changes in the anatomy of the teeth because of tooth surface loss was measured using the basic erosive wear examination (BEWE) ${ }^{[13]}$ which is a validated index for both practice-based assessment and epidemiological studies. ${ }^{[9]}$

\section{MATERIALS AND METHODS}

A cross-sectional clinic-based survey of young adults was conducted in seven states and the Federal Capital Territory (Abuja) of Nigeria. The states represented the six geopolitical zones of Nigeria. Ethical approval was given by Health Research Ethics Committees. This study was part of a larger study which was fashioned after a similar study called European Study in NonCarious Cervical Lesions (Escarcel). Escarcel ${ }^{[14]}$ is a Pan European study designed to estimate the levels of sensitivity, periodontal disease, and tooth wear in young adults. Permission to use the Escarcel study protocol was granted by members of the European study group. The Nigerian study group comprised of 13 dentists including a National coordinator, drawn from public and private hospitals.

Participants were recruited from patients attending designated dental centers in each of the seven states during the study period of 6 months. Two centers located in rural/small-middle sized town and metropolitan city in each of the states were used. They were consenting patients who were in good general health, within the age range of 18 and 35 years, were able to read and understand English. They also had a minimum of six eligible teeth with no restorations. Exclusion criteria were the inability to communicate in English Language, presence of orthodontic appliance or cervical restorations in any of the six eligible teeth. Participants were also excluded if they were currently taking analgesic, received local anesthesia in the last $24 \mathrm{~h}$, and those who are on anticoagulants or have bleeding disorder or required prophylactic antibiotics for dental treatment. Employees of the study sites were also excluded from the study.

Each participant completed a questionnaire which was based on those used in the previous study identifying risk factors for tooth wear and dentine hypersensitivity ${ }^{[0,15]}$ but was modified to include some local factors (local tooth cleaning agents including salt, grounded charcoal, and broken plates) that are peculiar to our environment. The questionnaire included data on lifestyle, dietary, and oral health behavior.

Clinical examination of participants was performed by the investigators. Investigators were trained and calibrated by members of the European Escarcel study group at a training session in Lagos, Nigeria. A second training session was conducted after 2 weeks whereby the investigators' ability to assess teeth using the clinical protocol was evaluated. Intra-and inter-examined reliability was calculated according to the World Health Organization recommendation giving a kappa agreement of $85.5 \%$.

Teeth were dried using compressed air and examined without magnification under normal dental surgery conditions with good lighting. The cervical, facial, and oral (palatal/lingual) tooth surfaces were scored on all teeth (second molar to second molar) using the BEWE ${ }^{[13]}$ on a $0-3$ ordinal scale $(0=$ no wear, $1=$ early surface loss, $2=$ surface loss $<50 \%$, $3=$ surface loss $>50 \%$ ). Missing teeth, restored surfaces ( $>50 \%$ of the surface), traumatized or carious teeth and third molars were not scored.

Data were analyzed using IBM-Statistical Package for Service Solution (SPSS Inc., Chicago, IL, USA) Version 21.0). Bivariate analyses evaluated the proportion of participants who had facial/oral surface wear of BEWE score 2 or 3 for at least one tooth to a range of demographics, dietary, lifestyle, and oral care variables. Multiple regression analysis was conducted to predict tooth wear from the various factors.

\section{RESULTS}

A total of 1349 adults participated in the study. Six out of ten participants had a certain severity level of tooth 
surface wear $(60.2 \%)$. Highest tooth wear BEWE score 0 was seen in 537 patients (39.8\%), 1 for 279 (20.7\%), 2 for 397 (29.4\%), and 3 for 136 (10.1\%).

Bivariate analysis of demographic factors and tooth wear (BEWE Scores 2or 3) showed an increase in tooth wear with age. There were significant differences in tooth wear recorded as the BEWE scores 2 or 3 among the participants from the different states $(P=0.000)$ with significant levels of tooth wear observed in the Northern groups (Kano, Borno) and the Federal Capital, Abuja. Significant differences were also shown in the prevalence of tooth wear (BEWE Scores 2 or 3) with educational levels and occupation, especially among those that claimed they are house persons Table 1.
The most associated oral hygiene factors for tooth wear (BEWE score 2 or 3) was found in participants who brushed their teeth most frequently and those who use chewing stick and other local means to clean their teeth [Table 2]. The prevalence of tooth wear (BEWE scores 2 or 3) was not significantly associated with lifestyle factors, including snoring, use of sleeping medications/antidepressant, and chewing gum. However, occurrences of tooth wear (BEWE scores of 2 or 3) were found to increase with smoking [Table 3]. Despite high prevalence of tooth wear (BEWE score 2 or 3 ) related to most of the acidic dietary factors, there was no significant association with these factors [Table 4].

Multiple logistic regression analysis of the subjects' demographic factors, oral hygiene factors, dietary

\begin{tabular}{|c|c|c|c|c|c|c|c|c|}
\hline & \multirow[t]{2}{*}{$n$} & \multicolumn{2}{|c|}{ Erosive tooth wear } & \multirow[t]{2}{*}{ OR } & \multicolumn{2}{|c|}{$95 \%$ confidence limits } & \multirow[t]{2}{*}{$\chi^{2}$} & \multirow[t]{2}{*}{$P$} \\
\hline & & BEWE (2-3) & Percentage & & Lower & Upper & & \\
\hline Total patients & 1349 & 533 & 39.5 & & & & & \\
\hline Age (years) & 1303 & & & & & & & \\
\hline $18-25$ & 466 & 154 & 33.0 & 0.66 & 0.52 & 0.83 & 26.86 & $0.000^{*}$ \\
\hline $26-35$ & 837 & 347 & 41.5 & 1.24 & 0.99 & 1.56 & & \\
\hline Gender & 1329 & & & & & & & \\
\hline Male & 592 & 218 & 36.8 & 0.82 & 0.66 & 1.02 & 3.39 & 0.071 \\
\hline Female & 737 & 308 & 41.8 & 1.24 & 0.99 & 1.54 & & \\
\hline Centre & 1349 & & & & & & & \\
\hline Osun & 200 & 45 & 22.5 & 0.39 & 0.28 & 0.56 & 89.53 & $0.000^{*}$ \\
\hline Oyo & 200 & 54 & 27.0 & 0.52 & 0.37 & 0.72 & & \\
\hline Edo & 100 & 39 & 39.0 & 0.98 & 0.64 & 1.48 & & \\
\hline Enugu & 100 & 35 & 35.0 & 0.81 & 0.53 & 1.24 & & \\
\hline Kano & 200 & 96 & 48.0 & 1.50 & 1.11 & 2.03 & & \\
\hline Lagos & 250 & 90 & 36.0 & 0.83 & 0.63 & 1.11 & & \\
\hline FCT & 200 & 114 & 57.0 & 2.31 & 1.70 & 3.13 & & \\
\hline Borno & 99 & 60 & 60.6 & 2.52 & 1.66 & 3.84 & & \\
\hline Area of residence & 1147 & & & & & & & \\
\hline Rural & 395 & 158 & 40.0 & 1.03 & 0.81 & 1.31 & 0.423 & 0.807 \\
\hline $\begin{array}{l}\text { Small/mid-size } \\
\text { towns }\end{array}$ & 100 & 38 & 38.0 & 0.93 & 0.61 & 1.42 & & \\
\hline Metropolitan zone & 652 & 248 & 38.0 & 0.89 & 0.71 & 1.10 & & \\
\hline Education & 828 & & & & & & & \\
\hline To age $15+$ & 265 & 130 & 49.1 & 1.63 & 1.24 & 2.13 & 15.96 & $0.001^{*}$ \\
\hline To age $16-19$ & 106 & 46 & 43.4 & 1.19 & 0.80 & 1.78 & & \\
\hline To age $20+$ & 185 & 73 & 39.5 & 1.00 & 0.73 & 1.37 & & \\
\hline Still studying & 272 & 88 & 32.4 & 0.68 & 0.51 & 0.90 & & \\
\hline Occupation & 1238 & & & & & & & \\
\hline Self employed & 201 & 70 & 34.8 & 0.79 & 0.58 & 1.08 & 16.44 & $0.012^{*}$ \\
\hline Managers & 28 & 8 & 28.6 & 0.61 & 0.27 & 1.39 & & \\
\hline Other white collars & 335 & 144 & 43.0 & 1.21 & 0.94 & 1.56 & & \\
\hline Manual workers & 61 & 23 & 37.7 & 0.92 & 0.54 & 1.57 & & \\
\hline House person & 101 & 53 & 52.5 & 1.77 & 1.18 & 2.65 & & \\
\hline Unemployed & 97 & 36 & 37.1 & 0.90 & 0.59 & 1.37 & & \\
\hline Student & 415 & 143 & 34.5 & 0.73 & 0.58 & 0.93 & & \\
\hline
\end{tabular}




\begin{tabular}{|c|c|c|c|c|c|c|c|c|}
\hline & \multirow[t]{2}{*}{$n$} & \multicolumn{2}{|c|}{ Erosive tooth wear } & \multirow[t]{2}{*}{ OR } & \multicolumn{2}{|c|}{$95 \%$ confidence limits } & \multirow[t]{2}{*}{$\chi^{2}$} & \multirow[t]{2}{*}{$P$} \\
\hline & & BEWE (2-3) & Percentage & & Lower & Upper & & \\
\hline Total patients & 1349 & 533 & 39.5 & & & & & \\
\hline Brushing frequency & 1265 & & & & & & & \\
\hline Once per day & 1009 & 373 & 37.0 & 0.66 & 0.52 & 0.85 & 11.21 & $0.003^{*}$ \\
\hline Twice per day & 247 & 116 & 47.0 & 1.45 & 1.10 & 1.92 & & \\
\hline Thrice per day & 9 & 6 & 66.9 & 3.09 & 0.77 & 12.39 & & \\
\hline Toothbrush used & 1265 & & & & & & & \\
\hline None & 21 & 6 & 28.6 & 0.61 & 0.23 & 1.58 & 2.16 & 0.702 \\
\hline Manual toothbrush & 1193 & 467 & 39.1 & 0.88 & 0.63 & 1.23 & & \\
\hline Electric toothbrush & 26 & 10 & 38.5 & 0.96 & 0.43 & 2.12 & & \\
\hline Chewing stick & 18 & 8 & 44.4 & 1.23 & 0.48 & 3.13 & & \\
\hline Others & 7 & 4 & 57.1 & 2.05 & 0.46 & 9.19 & & \\
\hline Brush movement & 1329 & & & & & & & \\
\hline Various motion & 403 & 162 & 40.2 & 1.04 & 0.82 & 1.32 & 11.56 & $0.020^{*}$ \\
\hline Horizontal & 334 & 153 & 45.8 & 1.41 & 1.10 & 1.81 & & \\
\hline Vertical & 517 & 178 & 34.4 & 0.71 & 0.56 & 0.89 & & \\
\hline Circular & 53 & 23 & 43.4 & 1.18 & 0.68 & 2.05 & & \\
\hline Don't know/not sure & 22 & 9 & 40.9 & 1.06 & 0.45 & 2.50 & & \\
\hline Brush after breakfast & 1349 & & & & & & & \\
\hline Often & 437 & 148 & 33.9 & 0.70 & 0.55 & 0.89 & 10.34 & $0.035^{\star}$ \\
\hline Occasionally & 215 & 87 & 40.5 & 1.05 & 0.78 & 1.41 & & \\
\hline Rarely & 240 & 101 & 42.1 & 1.39 & 0.86 & 1.51 & & \\
\hline Never & 303 & 125 & 41.3 & 1.10 & 0.85 & 1.42 & & \\
\hline Don't know & 154 & 72 & 46.8 & 1.40 & 1.00 & 1.96 & & \\
\hline Brush before breakfast & 1349 & & & & & & & \\
\hline Often & 1004 & 403 & 40.1 & 1.11 & 0.86 & 1.43 & 4.44 & 0.34 \\
\hline Occasionally & 195 & 71 & 36.4 & 0.86 & 0.63 & 1.18 & & \\
\hline Rarely & 72 & 33 & 45.8 & 1.32 & 0.82 & 2.12 & & \\
\hline Never & 70 & 22 & 31.4 & 0.69 & 0.41 & 1.16 & & \\
\hline Don't know & 8 & 4 & 50.0 & 1.54 & 0.38 & 6.16 & & \\
\hline Brush after lunch & 1349 & & & & & & & \\
\hline Often & 40 & 15 & 37.5 & 0.92 & 0.48 & 1.75 & 1.72 & 0.788 \\
\hline Occasionally & 72 & 27 & 37.5 & 0.91 & 0.56 & 1.49 & & \\
\hline Rarely & 533 & 205 & 38.5 & 0.93 & 0.74 & 1.16 & & \\
\hline Never & 687 & 281 & 40.9 & 1.13 & 0.91 & 1.40 & & \\
\hline Don't know & 17 & 5 & 29.4 & 0.63 & 0.22 & 1.81 & & \\
\hline \multicolumn{9}{|l|}{ Brush after dinner } \\
\hline Often & 385 & 164 & 42.6 & 1.20 & 0.94 & 1.52 & 6.23 & 0.183 \\
\hline Occasionally & 306 & 111 & 36.3 & 0.84 & 0.64 & 1.09 & & \\
\hline Rarely & 299 & 128 & 42.8 & 1.19 & 0.92 & 1.54 & & \\
\hline Never & 330 & 121 & 36.7 & 0.85 & 0.66 & 1.10 & & \\
\hline Don't know & 29 & 9 & 31.0 & 0.68 & 0.31 & 1.51 & & \\
\hline
\end{tabular}

factors, and other lifestyle factors showed that only the oral hygiene practices predict tooth wear. These oral hygiene factors; brushing frequency, brushing movement, brush after breakfast, brush before breakfast, brush after lunch and brush after dinner, significantly predict toothwear. $\mathrm{F}(6,1241)=3.500$, $P=0.002(P<0.005), R^{2}=0.017$. Specifically, brushing frequency, and brushing after breakfast as shown in Table 5, added significantly to the prediction $(P<0.05)$.

\section{DISCUSSION}

Assessment of the prevalence of tooth wear of young adults was necessary following reports ${ }^{[16,17]}$ that dentine hypersensitivity, a likely sequelae of tooth wear maybe common in this age group. In addition, a recent data (yet unpublished) indicated that Nigerian dentists reported that about $20 \%$ of their patients presenting with dentine hypersensitivity falls within this age group. 
Savage, et al:: A national survey of tooth wear on facial and oral surfaces and risk factors in young Nigerian adults

\begin{tabular}{|c|c|c|c|c|c|c|c|c|}
\hline & \multirow[t]{2}{*}{$n$} & \multicolumn{2}{|c|}{ Erosive tooth wear } & \multirow[t]{2}{*}{ OR } & \multicolumn{2}{|c|}{$95 \%$ confidence limits } & \multirow[t]{2}{*}{$\chi^{2}$} & \multirow[t]{2}{*}{$P$} \\
\hline & & BEWE (2-3) & Percentage & & Lower & Upper & & \\
\hline Total patients & 1349 & 533 & 39.5 & & & & & \\
\hline \multicolumn{9}{|l|}{ Snoring } \\
\hline Often & 88 & 32 & 36.4 & 0.87 & 0.55 & 1.36 & 7.91 & 0.095 \\
\hline Occasionally & 155 & 63 & 40.6 & 1.06 & 0.75 & 1.48 & & \\
\hline Rarely & 306 & 141 & 46.1 & 1.42 & 1.10 & 1.84 & & \\
\hline Never & 587 & 219 & 37.3 & 0.85 & 0.68 & 1.06 & & \\
\hline Don't know & 213 & 78 & 36.6 & 0.87 & 0.64 & 1.17 & & \\
\hline \multicolumn{9}{|c|}{ Sleeping medication/antidepressant } \\
\hline Often & 23 & 8 & 34.8 & 0.81 & 0.34 & 1.93 & 0.80 & 0.938 \\
\hline Occasionally & 64 & 27 & 42.2 & 1.12 & 0.68 & 1.87 & & \\
\hline Rarely & 235 & 93 & 39.6 & 1.00 & 0.75 & 1.33 & & \\
\hline Never & 991 & 389 & 39.3 & 0.96 & 0.75 & 1.23 & & \\
\hline Don't know & 36 & 16 & 44.4 & 1.23 & 0.63 & 2.40 & & \\
\hline \multicolumn{9}{|l|}{ Smoking } \\
\hline Often & 50 & 19 & 38.0 & 0.94 & 0.52 & 1.68 & 14.44 & $0.006^{*}$ \\
\hline Occasionally & 90 & 47 & 52.2 & 1.74 & 1.13 & 2.67 & & \\
\hline Rarely & 162 & 75 & 46.3 & 1.37 & 0.99 & 1.91 & & \\
\hline Never & 1030 & 382 & 37.1 & 0.61 & 0.58 & 0.63 & & \\
\hline Don’t know & 17 & 10 & 58.8 & 2.21 & 0.84 & 5.84 & & \\
\hline \multicolumn{9}{|l|}{ Chew gum } \\
\hline Often & 191 & 67 & 35.1 & 0.80 & 0.58 & 1.10 & 8.37 & 0.083 \\
\hline Occasionally & 580 & 241 & 41.6 & 1.16 & 0.93 & 1.45 & & \\
\hline Rarely & 333 & 131 & 39.3 & 0.99 & 0.77 & 1.28 & & \\
\hline Never & 216 & 77 & 35.6 & 0.82 & 0.61 & 1.11 & & \\
\hline Don't know & 29 & 17 & 58.6 & 2.21 & 1.05 & 4.66 & & \\
\hline
\end{tabular}

*Statistically significant. $O R=1$; factor does not have effect on tooth wear, $O R>1$; factor associated with high odds for tooth wear,

$\mathrm{OR}<1$; factor associated with lower odds for tooth wear. BEWE: Basic erosive wear examination, OR: Odds ratio

Results of this study indicated that facial/oral tooth surface wear when characterized as either mild or severe change in tooth surface anatomy was very common and seen in $60 \%$ of the participants. Although the prevalence is higher to that obtained among European population, ${ }^{[9]}$ the general prevalence trend was similar. The reasons for the high prevalence among the Nigerian population maybe because of difference in exposure to etiologic factors such as local cleaning agents (salt, chewing sticks, grounded charcoal/broken ceramic plates) which maybe more abrasive than toothpaste. Further support for this view from the result of this study was that the most associated oral hygiene factors for tooth wear were brushing frequency and the use of local cleaning agents. The use of local agents such as chewing sticks and locally prepared toothpaste had been previously reported among Nigerians. ${ }^{[18]}$ These agents are not as smooth as toothpaste and maybe more abrasive on the tooth surface.

The prevalence of tooth wear was found to increase with age of the participants. It can be inferred that as they get older the degree of tooth wear may further worsen with possibility of pulpal exposure. In view of this, it is important that efforts must be made to increase awareness concerning this condition and its associated risk factors. Increasing level of education was protective against having tooth wear. This may suggest that those with higher levels of education are aware of this condition and can implement preventive measures.

Findings in this study further confirmed Gillam et al. ${ }^{[19]}$ report that horizontal tooth brushing motion was found to cause more tooth wear than vertical brushing technique. This should reinforce the dentists' advice to patients not to use horizontal or scrubbing motion while the rolling, circular motion with the brush bristles at $45^{\circ}$ should be encouraged. Another risk factor for tooth wear is the timing of tooth brushing in relation to breakfast. While controversies persist in this regard concerning brushing before or after breakfast, the findings of this study showed that brushing after breakfast has effect on degree of tooth wear. The finding that smoking was strongly associated with tooth wear among the participants may be due to more 


\begin{tabular}{|c|c|c|c|c|c|c|c|c|}
\hline & \multirow[t]{2}{*}{$n$} & \multicolumn{2}{|c|}{ Erosive tooth wear } & \multirow[t]{2}{*}{ OR } & \multicolumn{2}{|c|}{$95 \%$ confidence limits } & \multirow[t]{2}{*}{$\chi^{2}$} & \multirow[t]{2}{*}{$P$} \\
\hline & & BEWE (2-3) & Percentage & & Lower & Upper & & \\
\hline Total patients & 1349 & 533 & 39.5 & & & & & \\
\hline \multicolumn{9}{|l|}{ Fresh fruits } \\
\hline Often & 390 & 156 & 40.0 & 1.03 & 0.81 & 1.31 & 3.31 & 0.511 \\
\hline Occasionally & 754 & 301 & 39.9 & 1.04 & 0.83 & 1.30 & & \\
\hline Rarely & 154 & 56 & 36.4 & 0.86 & 0.61 & 1.22 & & \\
\hline Never & 24 & 6 & 26.1 & 0.54 & 0.21 & 1.37 & & \\
\hline Don’t know & 27 & 13 & 48.1 & 1.43 & 0.67 & 3.07 & & \\
\hline \multicolumn{9}{|c|}{ Fruit/vegetable juice } \\
\hline Often & 340 & 138 & 40.6 & 1.06 & 0.83 & 1.36 & 4.71 & 0.319 \\
\hline Occasionally & 711 & 278 & 39.1 & 0.96 & 0.78 & 1.20 & & \\
\hline Rarely & 234 & 90 & 38.5 & 0.95 & 0.71 & 1.27 & & \\
\hline Never & 44 & 14 & 32.6 & 0.73 & 0.38 & 1.40 & & \\
\hline Don’t know & 20 & 12 & 60.0 & 2.33 & 0.95 & 5.73 & & \\
\hline \multicolumn{9}{|c|}{ Isotonic/energy drinks } \\
\hline Often & 81 & 38 & 46.9 & 1.38 & 0.88 & 2.17 & 8.77 & 0.067 \\
\hline Occasionally & 342 & 135 & 39.6 & 1.00 & 0.78 & 1.29 & & \\
\hline Rarely & 384 & 151 & 39.3 & 0.99 & 0.78 & 1.26 & & \\
\hline Never & 502 & 185 & 36.9 & 0.84 & 0.67 & 1.05 & & \\
\hline Don’t know & 40 & 23 & 57.5 & 2.12 & 1.12 & 4.01 & & \\
\hline \multicolumn{9}{|l|}{ Soft drinks } \\
\hline Often & 361 & 139 & 38.5 & 0.94 & 0.74 & 1.21 & 6.22 & 0.183 \\
\hline Occasionally & 679 & 276 & 40.6 & 1.10 & 0.89 & 1.37 & & \\
\hline Rarely & 222 & 80 & 36.0 & 0.84 & 0.62 & 1.13 & & \\
\hline Never & 67 & 25 & 37.3 & 0.91 & 0.55 & 1.51 & & \\
\hline Don’t know & 20 & 12 & 63.2 & 2.66 & 1.04 & 6.81 & & \\
\hline \multicolumn{9}{|l|}{ Dairy products } \\
\hline Often & 167 & 69 & 41.3 & 1.09 & 0.78 & 1.52 & 1.46 & 0.834 \\
\hline Occasionally & 570 & 220 & 38.6 & 0.94 & 0.75 & 1.17 & & \\
\hline Rarely & 446 & 172 & 38.6 & 0.94 & 0.75 & 1.19 & & \\
\hline Never & 126 & 54 & 42.9 & 1.17 & 0.80 & 1.69 & & \\
\hline Don't know & 40 & 17 & 43.6 & 1.19 & 0.63 & 2.26 & & \\
\hline \multicolumn{9}{|l|}{ Acidic foods } \\
\hline Often & 346 & 142 & 41.0 & 1.09 & 0.85 & 1.40 & 2.82 & 0.588 \\
\hline Occasionally & 591 & 226 & 38.2 & 0.91 & 0.73 & 1.13 & & \\
\hline Rarely & 280 & 116 & 41.4 & 1.11 & 0.85 & 1.45 & & \\
\hline Never & 109 & 38 & 34.9 & 0.81 & 0.54 & 1.21 & & \\
\hline Don't know & 23 & 11 & 47.8 & 1.41 & 0.62 & 3.22 & & \\
\hline
\end{tabular}

aggressive tooth brushing effort by the individuals to remove tobacco extrinsic stains on teeth surfaces. In addition, important in this action is probably the use of hard bristled tooth brush along with abrasive cleaning agents (e.g., grounded charcoal, broken plate) use of which was common among the participants. Tooth surface wear was more prevalent among the Northern participants. While specific reasons could not be ascribed to these findings, further investigation may be needed to ascertain probable risk factors.

Results of this study negate the reports ${ }^{[20,21]}$ that have identified acidic food items (Soft drinks, fruits) as being associated with tooth wear from erosive effects. However, frequent consumption of energy drinks among the participants indicated a high odd for tooth wear (odds ratio OR =1.3). This finding can be substantiated by the previous report that popular sports and energy drinks in the Nigerian market are acidic with mean titratable acidity ranges from 4.1 to $13.8 \mathrm{ml}$ and $\mathrm{pHs}$ well below the critical $\mathrm{pH}$ (5.5) of enamel demineralization. ${ }^{[2]}$ The finding of this study collaborated the protective actions of dairy products on the teeth which was also supported by Aidi et al. ${ }^{[23]}$ 
Savage, et al:: A national survey of tooth wear on facial and oral surfaces and risk factors in young Nigerian adults

\begin{tabular}{|c|c|c|c|c|c|c|c|c|}
\hline \multirow[t]{2}{*}{ Variables } & \multirow[t]{2}{*}{$n$} & \multicolumn{2}{|c|}{ Erosive tooth wear } & \multirow[t]{2}{*}{$B$} & \multirow[t]{2}{*}{ SE } & \multirow[t]{2}{*}{$\beta$} & \multirow[t]{2}{*}{$t$} & \multirow[t]{2}{*}{$P$} \\
\hline & & BEWE (2-3) & Percentage & & & & & \\
\hline \multicolumn{9}{|c|}{ Brushing frequency } \\
\hline Once per day & 1009 & 373 & 37.0 & 0.109 & 0.034 & 0.095 & 3.198 & $0.001^{*}$ \\
\hline Twice per day & 247 & 116 & 47.0 & & & & & \\
\hline Thrice per day & 9 & 6 & 66.9 & & & & & \\
\hline \multicolumn{9}{|l|}{ Brush movement } \\
\hline Various motion & 403 & 162 & 40.2 & -0.016 & 0.014 & -0.032 & -1.109 & 0.268 \\
\hline Horizontal & 334 & 153 & 45.8 & & & & & \\
\hline Vertical & 517 & 178 & 34.4 & & & & & \\
\hline Circular & 53 & 23 & 43.4 & & & & & \\
\hline Not sure & 22 & 9 & 40.9 & & & & & \\
\hline \multicolumn{9}{|c|}{ Brush after breakfast } \\
\hline Often & 437 & 148 & 33.9 & 0.026 & 0.011 & 0.074 & 2.420 & $0.016^{*}$ \\
\hline Rarely & 215 & 87 & 40.5 & & & & & \\
\hline Never & 240 & 101 & 42.1 & & & & & \\
\hline Don’t know & 303 & 125 & 41.3 & & & & & \\
\hline \multicolumn{9}{|c|}{ Brush before breakfast } \\
\hline Often & 1004 & 403 & 40.1 & -0.006 & 0.017 & -0.010 & -0.343 & 0.732 \\
\hline Occasionally & 195 & 71 & 36.4 & & & & & \\
\hline Rarely & 72 & 33 & 45.8 & & & & & \\
\hline Never & 70 & 22 & 31.4 & & & & & \\
\hline Don’t know & 8 & 4 & 50.0 & & & & & \\
\hline \multicolumn{9}{|l|}{ Brush after lunch } \\
\hline Often & 40 & 15 & 37.5 & 0.020 & 0.020 & 0.030 & 0.996 & 0.320 \\
\hline Occasionally & 72 & 27 & 37.5 & & & & & \\
\hline Rarely & 533 & 205 & 38.5 & & & & & \\
\hline Never & 687 & 281 & 40.9 & & & & & \\
\hline Don’t know & 17 & 5 & 29.4 & & & & & \\
\hline \multicolumn{9}{|l|}{ Brush after dinner } \\
\hline Often & 385 & 164 & 42.6 & -0.012 & 0.013 & -0.029 & -0.923 & 0.356 \\
\hline Occasionally & 306 & 111 & 36.3 & & & & & \\
\hline Rarely & 299 & 128 & 42.8 & & & & & \\
\hline Never & 330 & 121 & 36.7 & & & & & \\
\hline Don't know & 29 & 9 & 31.0 & & & & & \\
\hline
\end{tabular}

\section{CONCLUSION}

This national study discovered that facial/oral tooth surface wear is very common among young Nigerian adults. Possible risk factors with high association are oral hygiene measures, especially frequency, horizontal tooth brushing motion, and the use of local tooth cleaning agents such as chewing sticks. Smoking and consumption of energy drinks were also contributory. It is important that the dental profession and relevant stakeholders take actions to increase public awareness for this dental condition.

\section{Acknowledgments}

The authors would like to acknowledge GlaxoSmithKline Consumer Nigeria PLC for supporting this study with a grant. The funders had no role in the study design, data collection and analysis, or preparation of the manuscript.

Financial support and sponsorship

This study was financially supported by GlaxoSmithKline Consumer Nigeria PLC.

\section{Conflicts of interest}

There are no conflicts of interest.

\section{REFERENCES}

1. Ganss C, Young A, Lussi A. Tooth wear and erosion: Methodological issues in epidemiological and public health research and the future research agenda. Community Dent Health 2011;28:191-5.

2. Smith BG, Knight JK. An index for measuring the wear of teeth. Br Dent J 1984;156:435-8.

3. Bartlett D, Smith BG. Definition, classification and clinical assessment of attrition, erosion and abrasion of enamel and dentine. In: Addy M, 
Embery G, Edgar WM, Orchardson R, editors. Tooth Wear and Sensitivity. London: Martin Dunitz; 2000. p. 87-92.

4. Grippo JO. Abfractions: A new classification of hard tissue lesions of teeth. J Esthet Dent 1991;3:14-9.

5. Dugmore CR, Rock WP. The prevalence of tooth erosion in 12-year-old children. Br Dent J 2004;196:279-82.

6. Van't Spijker A, Rodriguez JM, Kreulen CM, Bronkhorst EM, Bartlett DW, Creugers NH, et al. Prevalence of tooth wear in adults. Int J Prosthodont 2009;22:35-42.

7. Cunha-Cruz J, Pashova H, Packard JD, Zhou L, Hilton TJ; for Northwest PRECEDENT. Tooth wear: Prevalence and associated factors in general practice patients. Community Dent Oral Epidemiol 2010;38:228-34.

8. Bartlett DW, Fares J, Shirodaria S, Chiu K, Ahmad N, Sherriff M, et al. The association of tooth wear, diet and dietary habits in adults aged 18-30 years old. J Dent 2011;39:811-6.

9. Bartlett DW, Lussi A, West NX, Bouchard P, Sanz M, Bourgeois D, et al. Prevalence of tooth wear on buccal and lingual surfaces and possible risk factors in young European adults. J Dent 2013;41:1007-13.

10. Al-Dlaigan $\mathrm{YH}$, Shaw L, Smith A. Dental erosion in a group of British 14-year-old, school children. Part I: Prevalence and influence of differing socioeconomic backgrounds. Br Dent J 2001;190:145-9.

11. Taiwo JO, Ogunyinka A, Onyeaso CO, Dosumu OO. Tooth wear in the elderly population in south east local government area in Ibadan, Nigeria. Odontostomatol Trop 2005;28:9-14.

12. Oginni O, Olusile AO. The prevalence, aetiology and clinical appearance of tooth wear: The Nigerian experience. Int Dent J 2002;52:268-72.

13. Bartlett D, Ganss C, Lussi A. Basic erosive wear examination (BEWE): A new scoring system for scientific and clinical needs. Clin Oral Investig 2008;12 Suppl 1:S65-8.

14. European Study in Non Carious Cervical Lesions. Available from: ttps://odontologie.univ-lyon1.fr/servlet/com.univ.collaboratif.utils LectureFichiergw?ID_FICHIER= 1320402927928\&ID_FICHE=22813. [Last accessed on $201 \overline{8}$ Apr 04].

15. West NX, Sanz M, Lussi A, Bartlett D, Bouchard P, Bourgeois D, et al. Prevalence of dentine hypersensitivity and study of associated factors: A European population-based cross-sectional study. J Dent 2013;41:841-51

16. Bamise CT, Kolawole KA, Oloyede EO, Esan TA. Tooth sensitivity experience among residential university students. Int J Dent Hyg 2010;8:95-100.

17. Oderinu OH, Savage KO, Uti OG, Adegbulugbe IC. Prevalence of self-reported hypersensitive teeth among a group of Nigerian undergraduate students. Niger Postgrad Med J 2011;18:205-9.

18. Oke GA, Bankole OO, Denloye OO, Danfillo IS, Enwonwu CO. Traditional and emerging oral health practices in parts of Nigeria. Odontostomatol Trop 2011;34:35-46.

19. Gillam DG, Aris A, Bulman JS, Newman HN, Ley F. Dentine hypersensitivity in subjects recruited for clinical trials: Clinical evaluation, prevalence and intra-oral distribution. J Oral Rehabil 2002;29:226-31.

20. O'Sullivan EA, Curzon ME. A comparison of acidic dietary factors in children with and without dental erosion. ASDC J Dent Child 2000;67:186-92, 160.

21. Lussi A, Schaffner M. Progression of and risk factors for dental erosion and wedge-shaped defects over a 6-year period. Caries Res 2000;34:182-7.

22. Bamise CT, Oderinu OH. Erosive potential: Laboratory evaluation of sports drinks available in Nigerian market. Afr J Basic Appl Sci 2013;5:139-44.

23. Aidi HE, Bronkhorst EM, Huysmans MC, Truin GJ. Factors associated with the incidence of erosive wear in upper incisors and lower first molars: A multifactorial approach. J Dent 2011;39:558-63. 